\title{
Dionysian Eros or Erotic Dionysus? Sources and Meanings of Hybridization in the Bacchus Mosaic at the Naples Museum
}

\author{
Dionysiak Eros mu, Erotik Dionysos mu? Napoli Müzesi’ndeki \\ Bacchus Mozaiğindeki Melezleşmenin Kaynakları ve Anlamları
}

Nava SEVILLA-SADEH*

(Received 13 June 2020, accepted after revision 14 September 2021)

\begin{abstract}
The splendid mosaic exhibited at the Archeological Museum in Naples presents two enigmatic hybrid images: a feline composed of a tiger and a lion, and a figure that combines the characteristics of both Dionysus and Eros.

This study seeks to decipher the hybridization of these two mighty gods of the Roman world, Dionysus and Eros, as presented in the Naples museum mosaic. The main assumption is that two features link these two gods: madness, and the illusion of merging with the Divine. The hybridization of the two gods would seem to strengthen the significance of both and of their role as gods of transcendence, as revealed through an examination of Classical literary and philosophical sources.
\end{abstract}

Keywords: Dionysus, Eros, Platonic Philosophy, Neo-Platonism, Dionysian Mysteries.

Öz

Napoli'deki Arkeoloji Müzesi'nde sergilenen muhteşem mozaik, iki esrarengiz melez görüntü sunmaktadır: Kaplan ve aslandan oluşan bir kedi ve hem Dionysos hem de Eros'un özelliklerini birleştiren bir figür. Bu çalışma, Napoli Müzesi mozaiğinde sunulduğu şekliyle Roma dünyasının bu iki güçlü tanrısı Dionysos ve Eros'un melezleşmesini çözmeyi amaçlamaktadır. Ana varsayım, bu iki tanrıyı birbirine bağlayan iki özelliğin olmasıdır: Delilik ve Illahi olan ile birleşme yanılsaması. Klasik edebi ve felsefi kaynakların incelenmesiyle ortaya konduğu üzere, iki tanrının melezleştirilmesi, her ikisinin de aşkınlık tanrıları olarak rollerinin önemini güçlendiriyor gibi görünmektedir.

Anahtar Kelimeler: Dionysos, Eros, Platoncu Felsefe, Neo-Platonizm, Dionysos Gizemleri.

\footnotetext{
* Nava Sevilla-Sadeh, Department of Art History, Yolanda and David Katz Faculty of the Arts, Tel-Aviv University, 69978 Tel-Aviv, Israel. (iD) https:// orcid.org/0000-0001-5516-1213. E-mail: artcurator21@gmail.com
} 


\section{Introduction}

The splendid mosaic exhibited at the Archeological Museum in Naples (Fig. 1; Dunbabin 1999: 43-44) ${ }^{1}$, presents two enigmatic hybrid images: 1. a furred tiger with a lion's mane on a steep cliff. The hybrid is adorned with a vine wreath and appears to be ferocious, a typical Dionysian beast; and 2. a hybrid feline being ridden by a dual-nature figure featuring a plump childish body and wings as Eros, together with a vegetal wreath and a huge drinking cup as Dionysus. On the ground lies an object resembling a pole adorned with ribbons (taenia) that might be the Dionysian thyrsus, similar to that seen in a wall painting from Pompeii (Fig. 2). The thyrsus as an object is intensely connected with violence and ferocity and especially with the Maenads, and the pole features an unidentified object, seemingly an animal skin, at its top. As told by Euripides, at the height of the frenzy, the Maenads tore to pieces the young of hares and deer, and Pentheus's mother affixed her son's head atop her thyrsus, assuming it to be a fawn (Eur. Bacch. 1140-1141; For the relation of the taenia to the Dionysian context see: Plat. symp. 212d.e, 213d).

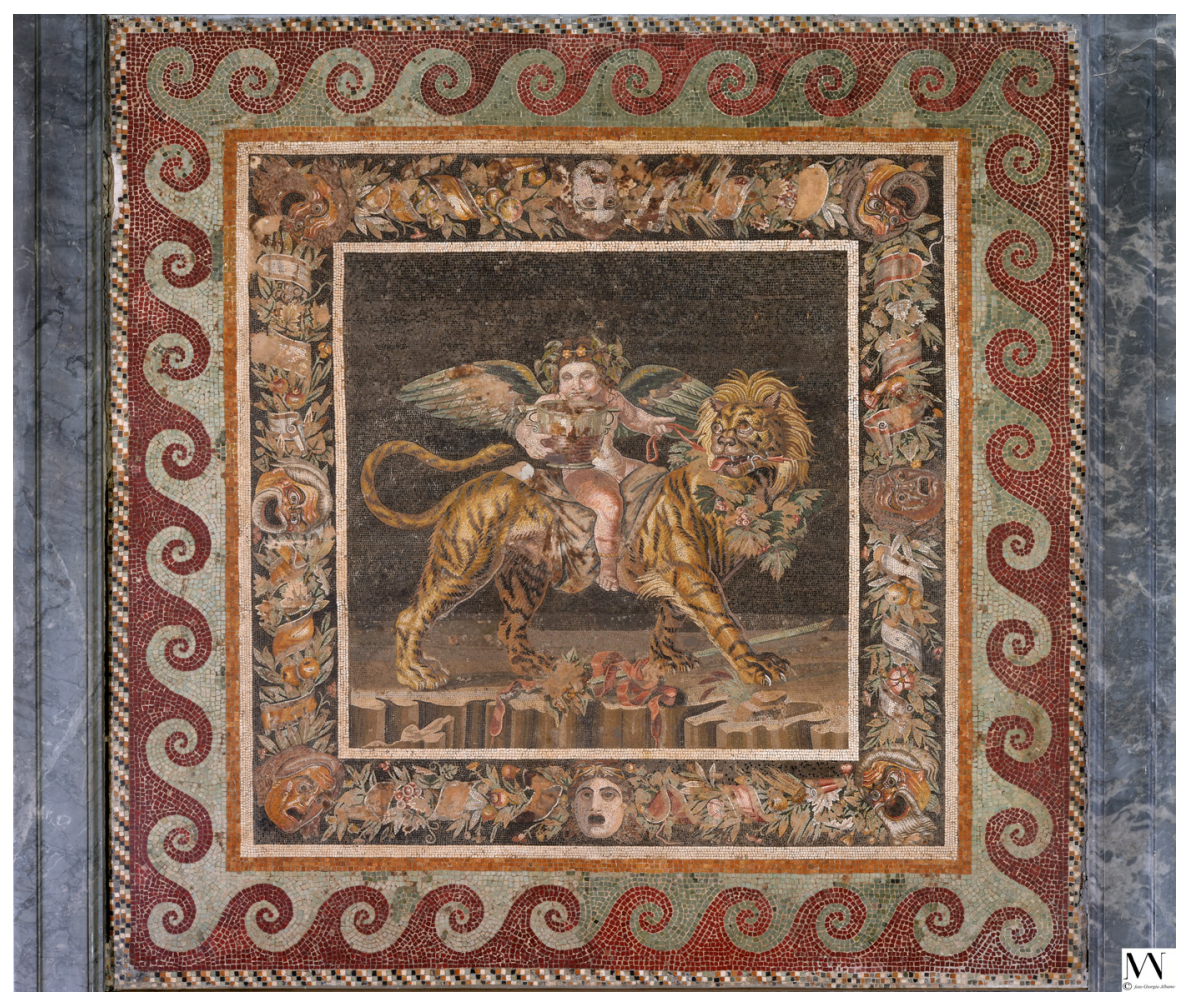

The depictions of the images in the mosaic are highly mimetic and vivid, as if seeking to become tangible to the beholder. Such mimesis was perceived by Longinus as a manifestation of the Sublime (Long. sublim. 13, 22).

This hybridization of the two divinities, Eros and Dionysus, is quite rare and uncommon. However, a precedent for this representation appears in a Hellenistic Greek mosaic at the Archaeological Museum of Delos dating from the $2^{\text {nd }}$ century $\mathrm{BC}$. This mosaic presents the god Dionysus with wings, holding the thyrsus with taenia, and riding a feline with the fur pattern of a tiger and the mane of a lion, while a golden cup is thrown in the side (Dunbabin 1999: 32).

However, hybridization had prevailed from the very beginning of Greek art, such
Figure 1

Young Dionysus on a Tiger, a mosaic from the house of the Faun, Pompeii.

Height: 165 x $165 \mathrm{~cm}$, around 100 BCE.

Su concessione del Ministero della Cultura

- Museo Archeologico Nazionalle di Napoli

- foto di Giorgio Albano (inv. 9991).

1 The mosaic technique is in Opus vermiculatum. It was created around $100 \mathrm{BC}$ and located in a triclinium (Room 34) in the House of the Faun. 
Figure 2

Dionysus and mount Vesovius, fresco, from the Lararium of the House of the Centenary, Pompeii, First Century AD. Su concessione del Ministero della Cultura - Museo

Archeologico Nazionalle di Napoli - foto di Giorgio Albano (inv. 112286).

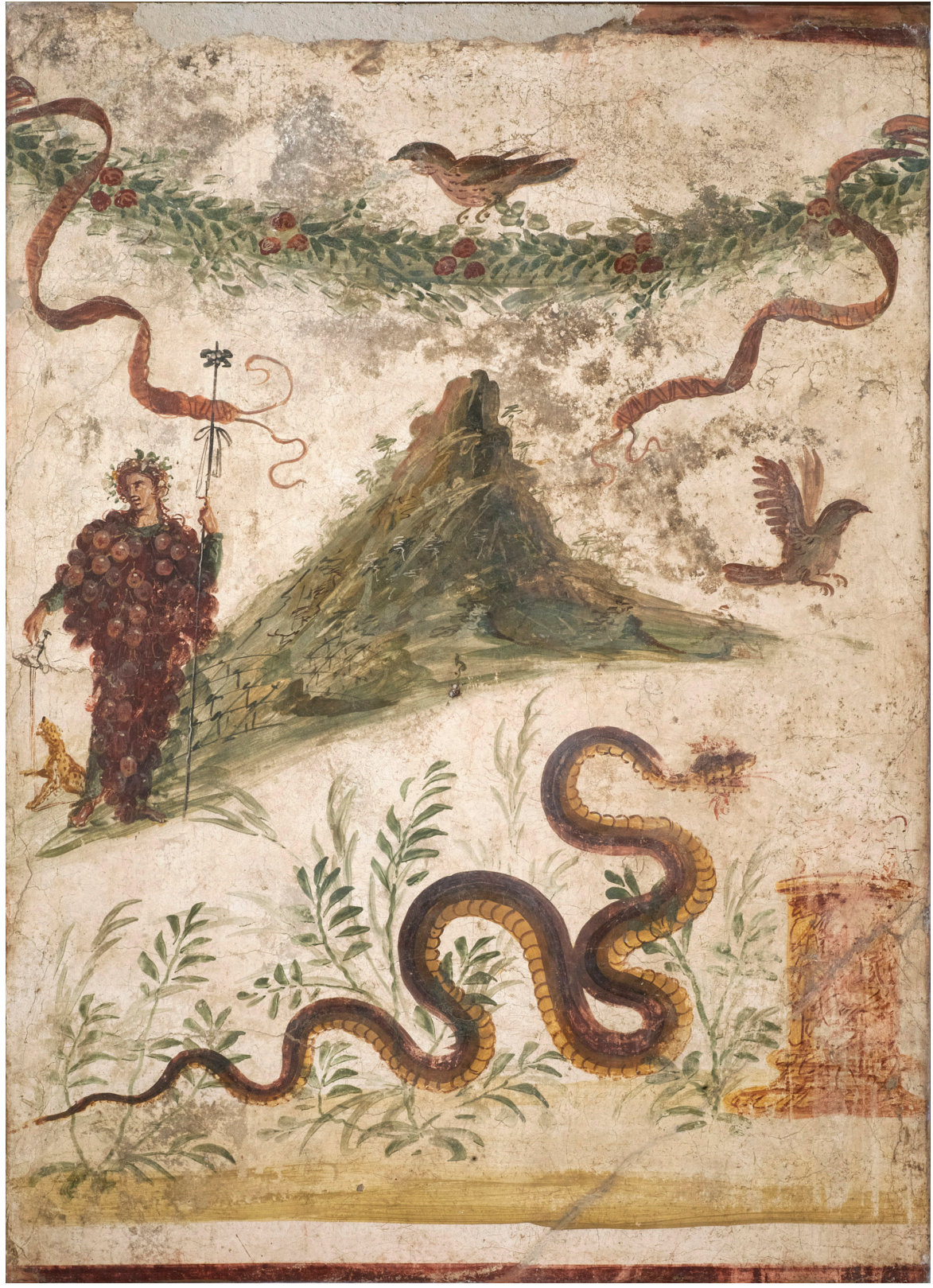

as in the images of griffins and sphinxes depicted in an Oriental style in Greek vase paintings of the $7^{\text {th }}$ Century BCE (Cook 1972: 41-153). Hybridization became increasingly common in the $6^{\text {th }}$ and $5^{\text {th }}$ centuries $\mathrm{BCE}$, mostly in the Dionysian image of the Satyr, as a mythological as well as hybrid artistic image. Hybridization was manifested too in the Satyrs in their portrayal as humans with animal ears, tail, and hooves. Their behavior is portrayed as lascivious and promiscuous, and they dance with abandon. This behavior, as depicted on Attic pottery, was meant to represent the opposite of the principle of aidos - the moderation and self-restraint to which the Greek citizen was obliged, and was thus connected with Otherness in xenophobic Athens of the $5^{\text {th }}$ century BCE (Durand et al. 1989; Lissarague 1990: 66; Lissarague 1992: 66; Cherry 1995: 139-140; Hedreen 2000: 292; On the principle of autochthon see: Hdt. I, a56; Loraux 1986: 148-150).

In addition to their social symbolism, and as Dionysian creatures, the satyrs were perceived as mediators between the earthly and the Divine, and hence they are demons (Mourão 2010: 183-184). 
The ecstasy that the Satyrs bring about during the Dionysian ritual was aimed at generating and consecrating exultation (Dettienne 1981: 224, 226; Durand et al. 1989: 126).

Another hybrid image in the Classical period is that of the Centaur, which appears in temple sculptures such as on the western gable of the temple to Zeus at Olympia, and on the Parthenon's metopes, as a savage and aggressive hybrid. Featuring an upper human torso and the body and legs of a horse, in addition to its fierce expression and deformed face resembling a mask, the Centaur was perceived as a brutal beast, savage and aischros (ugly), lacking the traits of Sophrosune (restraint, moderation) and Enkrateia (self-control). While the Centaurs embody hubris and pathos, the Lapiths, who fought the Centaurs, represented sophrosyne and arête (Hom. Od. 21. 289-315; Ov. met. 12.210-535; Robertson 1989 (1981): 86-87; Stewart 1990: 142-146; Cherry 1995: 139-140). Hybridity, in both the Satyrs and the Centaurs was thus aimed at strengthening their bestial features, and hence their particular social and religious roles, with the exception of Chiron, who was considered as wise and spiritual (Monteagudo 2012: 61-65).

Another hybrid, prominent mostly in the Hellenistic and Roman periods, is the hermaphrodite that is actually a metamorphosis resulting from the conjunction of a male and a female. This hybridization, manifested in androgyny, has been understood as reflecting the blurring of mental and geographical boundaries typical to the Hellenistic period. The hermaphrodite thereby invites a voyeuristic gaze that examines the weird and the Other (Stackelberg 2014: 404). This Other too might be perceived as Divine, since it is not only associated with the dangers of watching something that is taboo but, furthermore, androgyny constitutes a totality in which the Divine is manifested (McNally 1985: 174; Pollitt 1986: 149; Stewart 1997: 228-230; Platt 2002: 92-101; Elsner 2007: 22-24; Taylor 2008: 5-8, 57-58).

The image of the hermaphrodite was also interpreted as a manifestation of the desire for domestic harmony that mirrored the political concord ushered in by Augustus and Livia's reconciliation of the political factions following the civil wars. As a hybrid, the hermaphrodite was perceived as an omen of the divine order; and since the divine order establishes social order, the merging of male and female in the hermaphrodite mirrored the domestic order in Augustan times (Stackelberg 2014: 422-423).

In this study I discuss the fusion of the two mighty gods of the Roman world, Dionysus and Eros, as represented in the mosaic in the Naples museum, in an attempt to uncover the significance of this merging.

Common characteristics link these two gods: madness is a typical condition that attacks those who are influenced both by Dionysus and by Eros; and both confer transcendence upon their devotees. According to Socrates, madness is essentially positive and a gift from the gods, since it was Apollo who gave the gift of prophecy; Dionysus gave the mysteries; the Muses gave poetry; and Aphrodite gave love that is implemented by Eros (Plat. Phaidr. 265). Madness is therefore a common denominator of these two divinities, and hence their merging into one image here would seem to be the consequence of a deliberate and rational choice. The following discussion will focus on the significances of madness and of reaching transcendence in regard to these two gods. 


\section{Eros: Madness and the Sublime}

The image of the chubby winged child seems to reflect too the figure of the mighty and cosmic divinity of Eros. The potency of Eros derives from his connection with the creation of the universe as a result of pairings between gods and goddesses, as described by Hesiod and Ovid (Hes. theog. 120-122; Ov. met. 5. 380-384). Eros, as associated with sexual desire, is first and foremost a Creator and one of the mightiest gods in Antiquity.

Eros's mighty nature is portrayed in the Phaedrus dialogue by Plato. Eros is a mediator god who bestows the madness of love upon the souls in the mundane world. According to the parable in the dialogue, the human soul had witnessed the sublime and awesome beauty of the heavenly beings before she entered the corporeal sphere. After allegedly being "imprisoned" in a physical body, she forgot those astounding sights, other than a dim memory and an extreme yearning to witness them once more. Consequently, the soul is in a state of constant pursuit of this dim memory and, whenever she finds beauty in another soul, the memory of the wonderful divine beauty she had once witnessed returns to her, and she fills with love for this soul and an immense desire to merge with it (Plat. Phaidr. 251-252).

This perception of Eros as a mediator was preserved in the Neo-Platonic thought of Plotinus. Accordingly, the origin of the soul is the hen - the Absolute One, which is the origin of all, and the soul constantly yearns to return to this origin. Eros was perceived by Plotinus as a mediator between the soul and the wisdom that stems from the Divine, for which the soul yearns (Plot. enn. IV b 4, III 5 b, $c, d)$.

The Platonic parable and its Neo-Platonic interpretation allude to a relation between Eros and madness, since the soul falling in love enters into a state of madness. This feeling is similar to that caused by wine intoxication, hence the comparison between Eros and Dionysus (see Ov. ars I. 229, 244). The parable also alludes to the relation between Eros and death, since only death can release the soul from its corporeal prison and enable it to return to its origins and merge with the Divine. Both madness and death relate to the aspects of violence and boldness of this mighty god.

Indeed, Eros was portrayed in Greek literature as a bold hunter and trickster magician who takes over those who become trapped in his charms and dulls their senses, as manifested in Plato's Symposium: "[...] he is brave, impetuous, and intense, an awesome hunter, always weaving snares, resourceful in his pursuit of intelligence, a lover of wisdom through all his life, a genius with enchantments, potions, and clever pleadings" (Plat. symp. 203d-e; Thornton 1997: 18-20).

As noted by Jean Pierre Vernant, both love and death are related to Eros (Vernant 1991: 100). Emily Vermeule too has noted the affinity between love and death as a fundamental principle in certain Greek myths, as in the myth of Persephone and of Helen of Troy (Vermeule 1979: 159). The violent aspect of Eros and the relation between love and death is attested also in the myth of Ganymede: when a god is seized by the beauty of a human, he abducts that human from mortal life (Hom. Il. 20. 235-231; Ov. met. 10. 155-161; Vernant 1991: 102). The many abduction myths and portrayals in Greek and Roman art likewise reflect the relation between love and violence (Stewart 1995: 74-90; Cohen 1996: 117135). These myths and portrayals were interpreted on several levels. From the socio-political point of view abductions were related to the perception of women as savage beings that needed to be tamed by men; their subordination to 
men; and as metaphors of colonialism and settlement (Sourvinou-Inwood 1987: 138-140, 145, 152; Sutton 1992: 31; Keuls 1993: 51; Stewart 1995: 80; 1997: 156, 174-177). From a spiritual-religious point of view, and in relation to Eros, abductions were perceived as symbolizing the human desire to unit with the Divine (Kaempf-Dimitriadou 1979: 5, 43-58; Stewart 1995: 78).

The unity between a god and a mortal is therefore a violent one, and Eros is the mediator who instills within the human the passion to merge with the Divine.

In this context, it is important to note the story of Psyche and Cupid, and the tough initiation journey that Psyche went through until she was able to regain her love, metamorphosed into a butterfly that symbolizes the transformation of the soul, and gaining immortality. This myth has been interpreted as an allegory for the ancient mysteries. Cupid (Eros) is therefore the guide for the initiation, Psyche is the spiritual and transitory soul, and they both represented the union between the body and soul. The images of psyche in mosaics appear with bird or butterfly wings. Both kinds of wings symbolized the human soul, and the bird's wing may refer to Psyche's role as the loving spouse of Eros. Psyche rarely appears with bat wings, which indicate her as being a night creature (Mourão 2013: 59-63).

A particular myth that combines love, madness, and death caused by Eros is that of Phaedra and Hippolytus (Eur. Hipp.; Sen. Phaedr.). Phaedra was filled with an intense and uncontrollable love as a result of Aphrodite's revenge for Hippolytus's blasphemy against the goddess. Phaedra's mental state became one of madness and of such helplessness that her muscles failed her (Eur. Hipp. 198-199). Seneca's words refer to death as a result of this illness and mental state. Phaedra's nurse reveals to the chorus Phaedra's signs of illness: her fever, torments, restless, weakness, crying, and imbalance (Sen. Phaedr. 360-383). Phaedra asks her nurse to ruffle her hair, and expresses her sexual fantasies, while the shocked nurse begs her to stop (Eur. Hipp. 241). Phaedra admits to her nurse that this madness and terrible illness were caused by a powerful deity and that she has lost her reason (Eur. Hipp. 131-140, 176, 214, 239-241, 248, 765-66; Sen. Phaedr. 177-179, 184-185, 365). Phaedra is used as a tool by the goddess, and her suffering and death, and even the fact that she builds a temple to Aphrodite, do not touch the goddess at all (Thornton 1997: 62). The arrow, which is the attribute of Eros, constitutes his violent aspect, and indeed Phaedra is injured by his arrows that have pierced her with the madness of love (Thornton 1997: 28, 35).

The madness of love is discussed profoundly in Platonic dialogues such as Phaedrus and The Symposium. From a negative perspective, love was perceived as a disease that causes insanity and lack of control (Plat. Phaidr. 231-233, 239241). However, from a positive perspective, the madness of love inspired by Aphrodite and Eros causes the yearning to approach and merge with the divine sublime (Plat. Phaidr. 251-252). This dualism is embodied in the influence of these two gods - Aphrodite and Eros: Aphrodite Ourania, the motherless daughter of Uranus, together with Eros the mediator, transcends the human and instills within him the yearning to merge with the sublime; while Aphrodite Pandemos, the daughter of Zeus and Dione, instills the human cravings for the pleasures of the body; and Eros attacks reason and moderation. Hence, together they cause obsession, imbalance, and disaster (Plat. symp. 180-181; Plat. Phaidr. 243, 255; Thornton 1997: 17, 26). The destructive influence of Eros was described by Archilochus as such: "Miserable with desire, I lie lifeless, my bones shot through with thorny anguish sent by the gods" (Archil. 29); and: "Desire the limb-loosener, O my companion, has beat me down" (Archil. 267). 
Sappho portrays the influence of Eros as a disease: "[...] my tongue is broken. A delicate fire runs under my skin, my eyes see nothing, my ears roar, cold sweat rushes down me, trembling seizes me, I am greener than grass. To myself I seem needing but little to die [...]" (Sappho, 31); "Love shook my senses, like wind crashing on mountain oaks" (Sappho, 47). and: "Once again Love, that loosener of limbs, bittersweet and inescapable, crawling thing, seizes me" (Sappho, 130).

Diotima, the mysterious woman from Mantinea, determines in The Symposium that the motive for mating is common to both humans and animals and makes them sick (Plat. symp. 207); while in Timaeos by Plato, Eros is considered as conferring a mental illness (Plat. Tim. 91 b, $86 \mathrm{~d}, 73 \mathrm{c}$ ).

Indeed, mythological wars, quarrels, and debates were the result of passion instilled by Eros, as declared by Socrates (Plat. Phaidr. 66). As a destructive force, Eros was also associated with fire, as thermos Eros, poetically portrayed by Sappho: "A delicate fire runs under my skin" (Sappho, 31).

The response of melting caused by heat and humidity was used to characterize the influence of Eros, since passion melts reason and causes delusions and catastrophe, as in the case of Medea (Eur. Med.; Ov. met. VII 421-4). Delusions are related too to intoxication, and thus to the realm of Dionysus. Accordingly, Dionysian intoxication could function as an aphrodisiac, inflaming sexual passion (Thornton 1997: 22).

In spite of Eros's distinct connection with violence, his image in the mosaic from Pompeii lacks the arrow, his militant attribute. This tends to strengthen the relation between Eros and Dionysus and their fusion as being, rather, in the sense of exultation and transcendence, as will be shown below.

\section{Dionysus: Savagery and Mystery}

The image of Dionysus in the mosaic is associated with the large cup held by the figure, his ivy wreath, the hybridization of the tiger with the lion adorned with vines, the red ribbons on the ground, and the masks within the vegetal scrolls at the margins.

The savage aspect of Dionysus is embodied in the mosaic by the huge cup that alludes to the influence of wine, and by the hybrid feline with its ferocious facial expression, open mouth, and lolling tongue. Felines appear in relation to Dionysus in Greek iconography and to Bacchus in Roman iconography as either being ridden or as pulling the chariot of the god. In general, the god is depicted followed by all kinds of felines: tigers, lions, panthers, and lynxes. The role of these beasts is triple: they are his acolytes, namely assisting him in the religious cult and protecting him; they serve him for transport; and they are one of his metamorphoses (Jacome 2013: 526, 529-530). His disguise as a lion or a leopard reveals the fierceness and savagery of the god (Eur. Bacch. 1017-1019; Anton. Lib. 10.2; Nonn. Dion. 40.43-60; Otero 2013: 333-334).

The merged image of the tiger and lion seems eccentric, although each features individually in Roman Bacchic mosaics: e.g. a savage lion bears the infant Dionysus in a mosaic of a procession from El Djem (Fig. 3)2; a tiger bears the infant Dionysus on his back in a mosaic from Bardo (Fig. 4); and four tigers lead

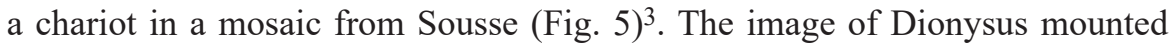
or led by a panther or tiger also appears in mosaics from the Iberian Peninsula (Blázquez 1984: 1-2, 8, 10).

2 Blanchard-Lemee et al.1996: 88-89 fig. 57. See also in the public domain: https://commons.wikimedia.org/wiki/File:El_Jem_Museum_dionysos_procession_mosaics.jpg

3 Blanchard-Lemée 1996 et al.: 89-96, 100-101 figs. 58, 64. See also in the public domain: https:// commons.wikimedia.org/wiki/File:Sousse_museum_mosaic_animals.jpg 


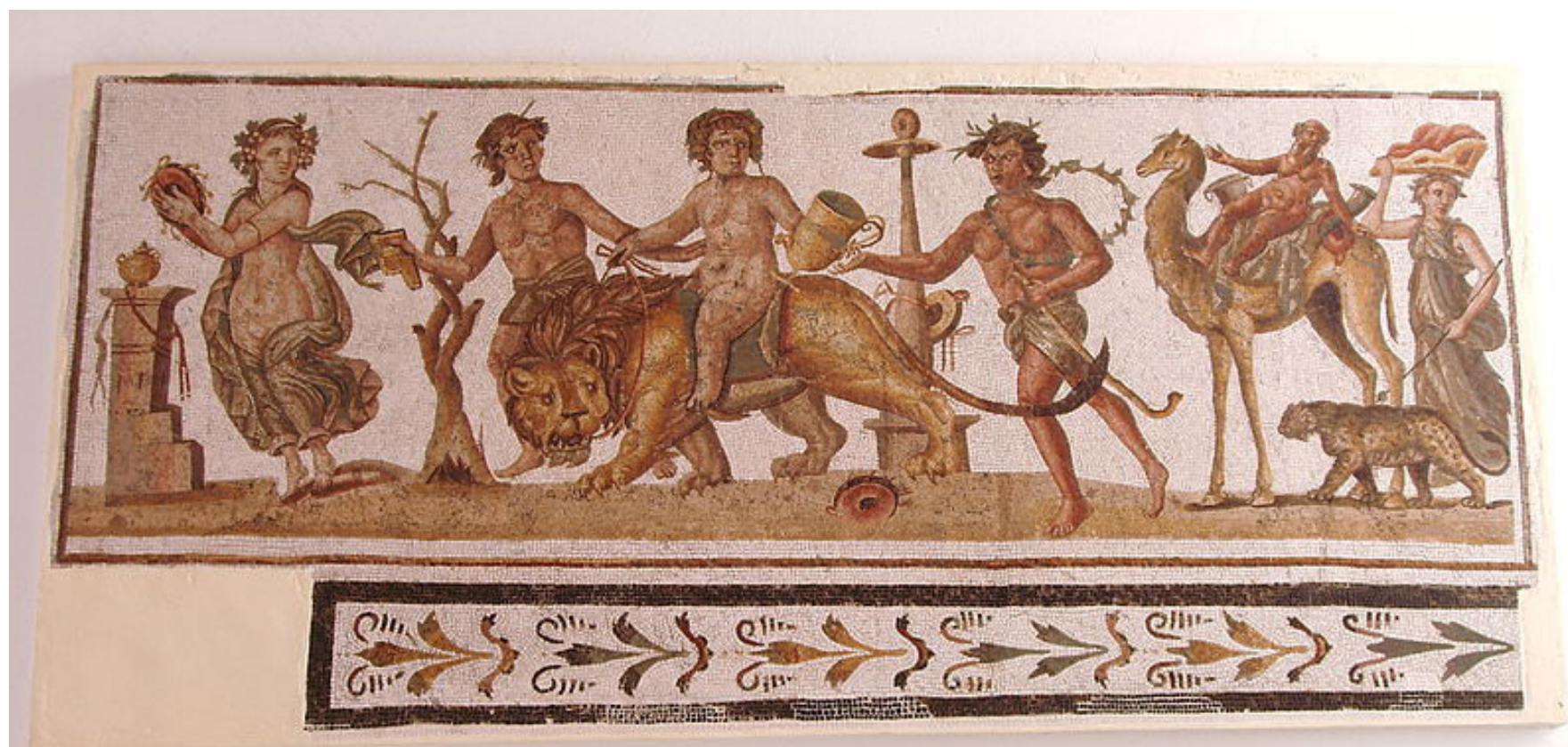

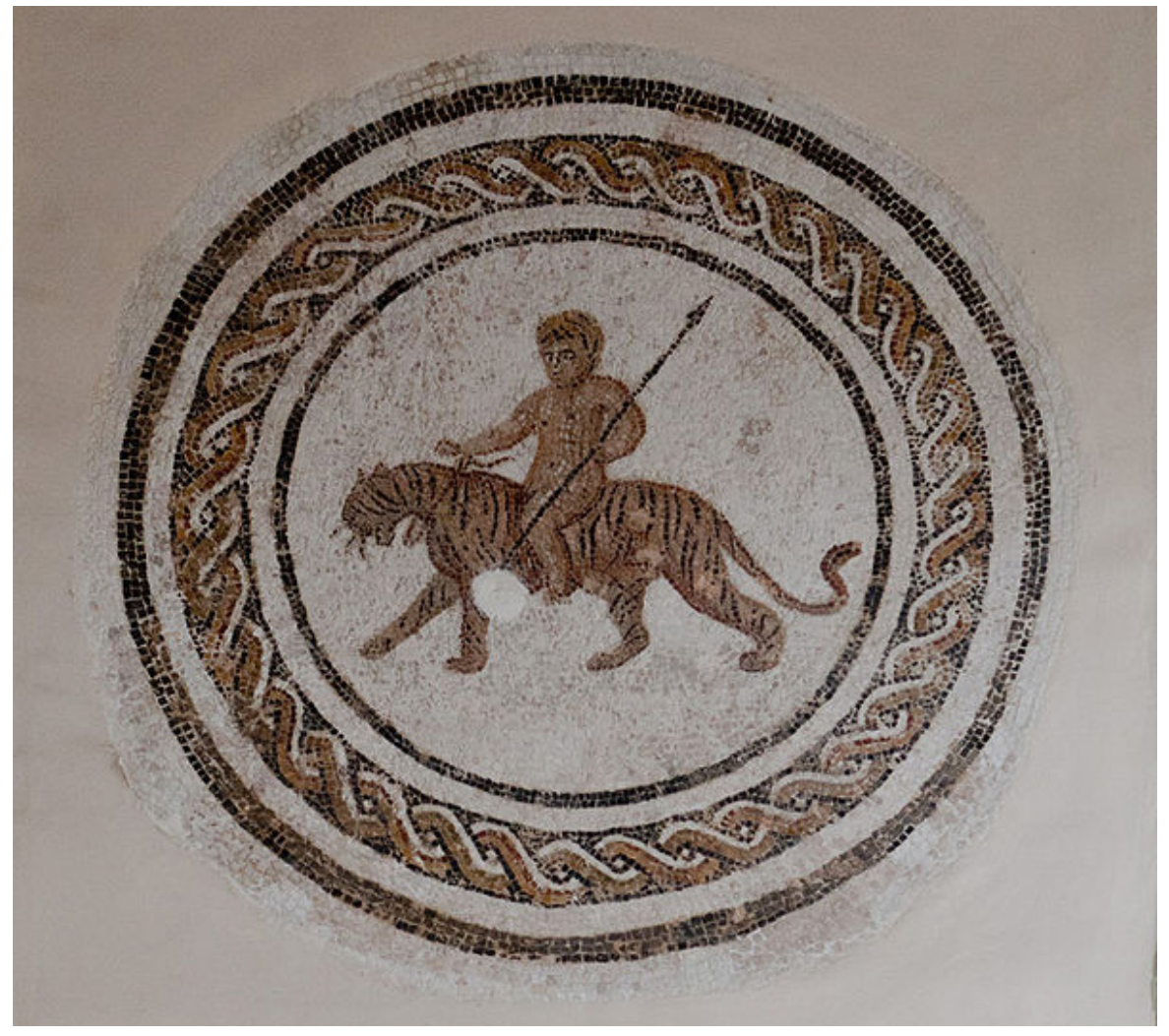

The hybrid image of the tiger and the lion discussed here presents an extreme representation, seemingly aimed at strengthening the savage Dionysian aspect.

This portrayal in the mosaic from Pompeii is reinforced by the images of the eight masks depicted between the vegetal marginal scrolls. The mask is a salient Dionysian object, appearing on Greek pottery and frequent in Roman mosaics. The mask symbolized the omnipresence of the god, his power, and the frenzy he induces upon his devotees, and the link between Dionysiac Mysteries and the ancient Theatre (Nilsson 1975: 74-78, 97-98; Otto 1981: 87-91; FrontisiDucroux 1989: 152-156, 163; See also in Villa of the Mysteries: Maiuri 1953:
Figure 3

Dionysus procession, mosaic, Second Century AD, $120 \times 260 \mathrm{~cm}$. Found at the House of Dionysian Procession, Thysdrus (El Djem, Tunisia). El Djem (Tunesia), Archaeological Museum. Public Domain Source: originally posted to Flickr as el jem museum mosaic dionysos procession Author: Damian Entwisle https://commons. wikimedia.org/wiki/File:El_Jem_Museum dionysos_procession_mosaics.jpg

Figure 4

Infant Dionysus riding tiger, mosaic from Acholla, Tunisia, Second Century AD, National Archeological Museum, Bardo, Tunisia. Public Domain Source: Own work Author: Jerzystrzelecki https://commons. wikimedia.org/wiki/File:Bardo(js)077.jpg 
Figure 5

Triumph of Bacchus, Ancient Roman mosaic, Third Century AD, Sousse Museum, Tunisia. Public Domain Source: http:// www.stoa.org/gallery/album21/P4140087 Author: Unknown https://commons. wikimedia.org/wiki/File:Triumph_of Bacchus - Sousse.jpg

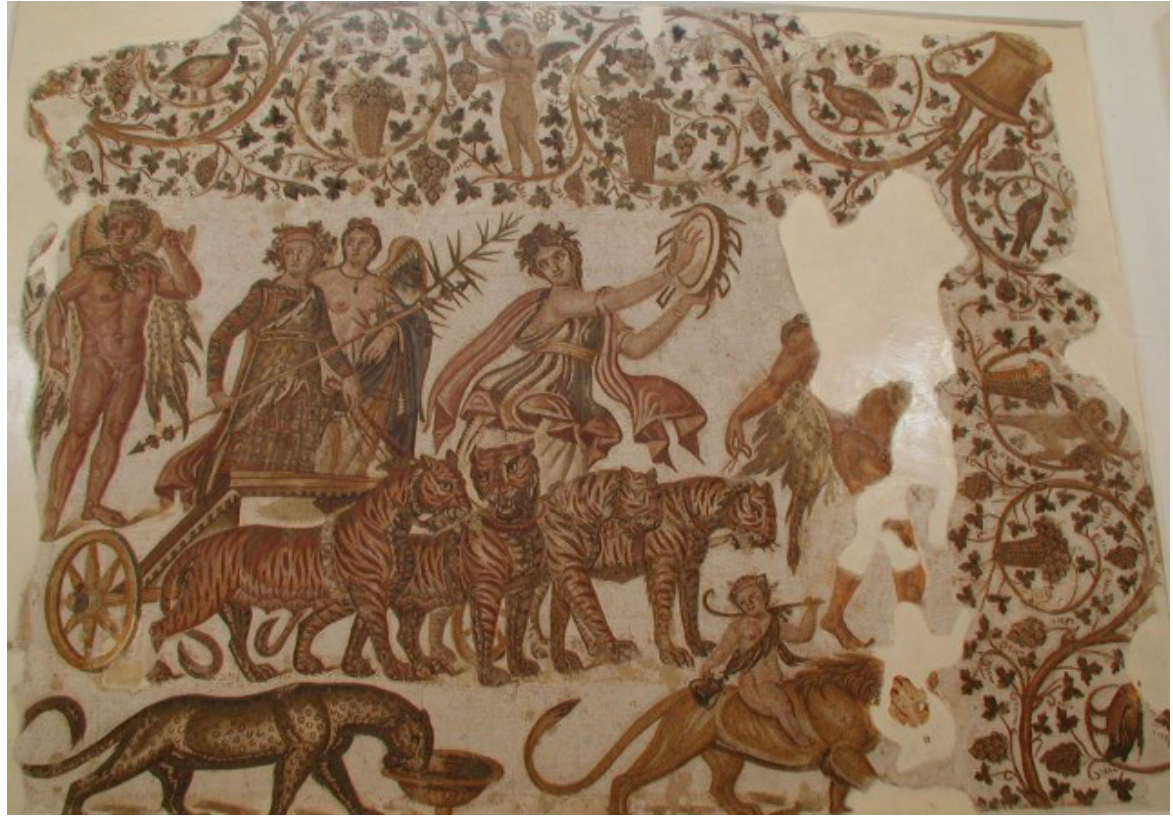

50-63; Meyer 1987: 63-65; Hendesron 1996: 235-276; Ling 1998: 101-104; Varone 2000: 106; Clarke 2003: 47-56).

Dionysian savagery is closely related to the main Dionysian practice - the Mysteries, which were secret rituals intended to bring about an illusion of merging with the Divine and of eternity in the afterlife. The Mysteries were widespread during the late Roman period, in the $2^{\text {nd }}-3^{\text {rd }}$ centuries AD. During the ritual a great secret was revealed to the participants - the mystai, promising them proximity to the god and everlasting happiness after death. The procedure of consecration required entering a state of ecstasy in order to reach the state of enthousiasmos - of being one with the god. This ecstasy finds expression in the wild dancing of the Maenads and Satyrs, as depicted accompanying the believers to their sanctification on Greek Archaic and Classical pottery. The debauchery of the god's companions conveys the frenzy and ecstasy that overcome the devotees in order for them to unite with the Divine (Frontisi-Ducroux 1989: 154, 156; Kerenyi 1996 (1976): 122, 123, 127, 128, 129, 130). In the course of the ritual a wild tumult erupts - pandemonium, which is the physical manifestation of the religious ecstasy. The wine, whose presence is dominant in the mosaic in the huge cup, is the device that enables this wild atmosphere. The intoxication caused by wine liberates the soul and induces an ecstasy that leads to the illusion of merging with the Divine. Dionysus is therefore a liberating god who enables the soul to regain its divine nature; and hence the god who realizes the Platonic vision of the illusion of uniting with the Divine (Bordoy 2013: 389, 391, 394, 398-399).

While Eros represents the urge of the human soul to experience the pursuit of the sublime, wine is the Dionysian device that enables realization of this urge. Since in his sober corporeal condition the human cannot view and experience the Divine, he needs some means by which to enter into the illusion of release from corporeality, as expressed by Plato:

"For all good poets, epic as well as lyric, compose their beautiful poems not by art, but because they are inspired and possessed. And as the Corybantian revelers when they dance are not in their right mind, so the lyric poets are not in their right mind when they are composing their beautiful strains: but when falling under the power of music and 
movement they are inspired and possessed; like Bacchic maidens who draw milk and honey from the rivers when they are under the influence of Dionysus but not when they are in their right mind" (Plat. Ion, 533-534).

The madness caused by Dionysus is a positive madness, since it enables the devotee to become entheos - to assimilate with the Divine (Eur. Bacch. 298-299; Plat. Phaidr. 264-265). Intoxication that derives from wine, being a controlled delusion, is therefore considered by Plato as a gift from the gods, and one that leads to catharsis - purification of the soul (Plat. Phaidr. 244-245; Lonsdale 1993: 79).

This view was expanded by Plotinus in Neo-Platonic thought. Accordingly, the origin of the soul is in the One (hen) in heaven, to which she constantly yearns to return. However, being corporeal, the only opportunity to experience an illusion of contemplating the One is through the removal of consciousness by means of a mysterious ecstasy, and wine is the device necessary to attain this ecstatic condition (Plot. enn. 5.8.10, 11; 6.9.4; 6.7.34-35; 6.9.9-11).

\section{Conclusions}

This study has focused on two kinds of hybrids depicted in the splendid mosaic from the Archeological Museum in Naples, and has sought to decipher the significances of these hybrids and their merging: a tiger with a lion; and its rider, which merges Eros with Dionysus and his attributes.

The premise underlying this study is that madness is a common feature to both Dionysus and Eros, and both divinities confer transcendence upon their devotees. These two common denominators would thus appear to be the reason for the merging of these two divinities, as examined here through an examination of classical literary and philosophical sources.

The image of the chubby, winged child seems to portray the figure of Eros, one of the mightiest gods in Antiquity, and under whose influence the soul enters into a state of madness, a state that is also the realm of the mighty god Dionysus.

The image of Dionysus in the mosaic is reinforced by the various attributes given to the figure. Savagery, as associated with Dionysus, is manifested in the mosaic by the hybrid feline and was part of the Dionysian practice, the Mysteries. The Dionysian ritual liberated the soul by means of intoxication attained through wine; and hence brought about ecstasy that led to an illusion of merging with the sublime Divine. Thus, Dionysus and his cult served as the means by which the Platonic and Neo-Platonic vision was realized, reinforced by Eros, whose attributes strengthen the spiritual role of Dionysus in connecting between the earthly and the Divine. In light of all the above, the image in the mosaic originally from Pompeii could be equally intended to represent a Dionysian Eros or an Erotic Dionysus. 


\section{Bibliography - Kaynaklar}

Blanchard-Lemée et al. 1996 M. Blanchard-Lemée - M. Ennaïfer-H. Slim - L. Slim, Mosaics of Roman Africa: Floor Mosaics from Tunisia, New York.

Blázquez 1984

Bordoy 2013

Benjamin 1900

Cherry 2003

Clarke 2003

Cohen 1996

Cook 1972

Cooper 1997

Davenport 1964

Dettienne 1981

Dunbabin 1999

Durand et al. 1989

Elsner 2007

Frontisi-Ducroux 1989

Hedreen 2000

Hendesron 1996

Jacome 2013

Kaempf-Dimitriadou 1979

Kerenyi 1996

Keuls 1993

Ling 1998

Lissarague 1990

Lissarague 1992

Lonsdale 1993

Loraux 1986

Maiuri 1953

McNally 1985

Meyer 1987

Monteagudo 2012

Mourão 2010

Mourão 2013
J. M. Blázquez, “Mosaicos báquicos en la Península Ibérica”, AEspA 57, 69-96.

C. F. Bordoy, "Dionysian Enthusiasm in Plato”, A. Bernabe - M. H. De Jauregui - M. Herrero, A. I. Jimenez San Cristobal - R. M. Hernandez (eds.), Redefining Dionysos, Berlin; Boston, 386-400.

J. Benjamin (trans.), The Dialogues of Plato, New York.

J. Cherry, Mythical Beasts, San Francisco.

J. Clarke, Roman Sex, 100 B.C.-A.D. 250, New York.

A. Cohen, "Portrayals of Abduction in Greek Art: Rape or Metaphor?", N. B. Kampen (ed.), Sexuality in Ancient Art: Near East, Egypt, Greece, and Italy, Cambridge, 117-135.

R. M. Cook, Greek Painted Pottery, London.

J. M. Cooper (ed.), Plato: Complete Works, Indianapolis/Cambridge.

G. Davenport (trans.), Carmina Archilochi: the Fragments of Archilochos, Berkeley and Los Angeles.

M. Dettienne, "Between Beasts and Gods", R. L. Gordon (ed.), Myth, Religion and Society: Structuralist Essays by M. Detienne, L. Gernet, J.-P. Vernant and P. Vidal-Nacquet, Cambridge, 215-228.

K. M. D. Dunbabin, Mosaics of the Greek and Roman World, Cambridge.

J. L. Durand - F. Frotisi-Ducroux - F. Lissarague, "Wine: Human and Divine", C. Berard (ed.), A City of Images: Iconography and Society in Ancient Greece, Princeton, 121-130.

J. Elsner, "Viewing Ariadne: From Ekphrasis to Wall Painting in the Roman World", C1Phil 102/1, 20-44.

F. Frontisi-Ducroux, "In the Mirror of the Mask", C. Berard (ed.), A City of Images: Iconography and Society in Ancient Greece, Princeton, 151-165.

G. Hedreen, “'I Let Go My Force Just Touching Her Hair': Male Sexuality in Athenian Vase-Paintings of Silens in Iambic Poetry", ClAnt 25, 277-325.

J. Hendesron, "Footnote: Representation in the Villa of the Mysteries", J. Elsner (ed.), Art and Text in Roman Culture, Cambridge, 235-276.

P. M. Jacome, "Bacchus and Felines in Roman Iconography: Issues of Gender and Species", A. Bernabe - M. H. de Jauregui - A. I. Jimenez San Cristobal - R. M. Hernandez (eds.), Redefining Dionysos, Berlin, Boston, 526-540.

S. Kaempf-Dimitriadou, Die Liebe der Gotter in der attischen Kunst des 5. Jahrhunderts v. Chr., Bern.

K. Kerenyi, Dionysus: Archetypal Image of Indestructible Life, Princeton N. J.

E. Keuls, The Reign of the Phallus - Sexual Politics in Ancient Athens, Berkeley.

R. Ling, Ancient Mosaics, Princeton N. J.

F. Lissarague, "The Sexual Life of Satyrs", D. M. Halperin - J. J. Winkler - F. I. Zeitlin (eds.), Before Sexuality: the Construction of Erotic Experience in the Ancient Greek World, Princeton N.J, 53-82.

F. Lissarague, The Aesthetics of the Greek Banquet: Images of Wine and Ritual, Princeton.

S. Lonsdale, Dance and Ritual Play in Greek Religion, Baltimore.

N. Loraux, The Invention of Athens - The Funeral Oration in the Classical City, Cambridge Mass.

M. Amadeo, Roman Painting, Geneva.

S. McNally, "Ariadne and Others: Images of Sleep in Greek and Early Roman Art”, ClAnt 4/2, $152-192$.

M. W. Meyer, The Ancient Mysteries: A Sourcebook, San Francisco.

G. L. Monteagudo, “La Ensoñación de la Guerra. Amazonas y Centauros”, L. Neira (ed.), Civilización y Barbarie: el Mito como Argumento en los Mosaicos Romanos, El Boalo, 53-68.

C. Mourão, AVTEM NON SVNT RERVM NATVRA. Figurações heteromórficas em mosaicos hispanoromanos, Lisboa.

C. Mourão, “Las Bodas Místicas del Cuerpo y el Alma: Cupido y Psique en los Mosaicos Romanos”, L. Neira (ed.), Desnuso y Cultura: La Construcción del Cuerpo en los Mosaicos Romanos La Construcción del Cuerpo en los Mosaicos Romanos, El Boalo, 59-80. 
Nilsson 1975

Otero 2013

Otto 1981

Platt 2002

Pollitt 1986

Rayor 2014

Robertson 1989 (1981)

Sourvinou-Inwood 1987

Stewart 1990

Stewart 1995

Stewart 1997

Stackelberg 2014

Sutton 1992

Taylor 2008

Thornton 1997

Varone 2000

Vermeule 1979

Vernant 1991
M. P. Nilsson, The Dionysiac Mysteries of the Hellenistic and Roman Age, New York.

S. M. Otero, "The Image of Dionysos in Euripides' Bacchae: The God and his Epiphanies", A. Bernabe - M. H. de Jauregui - A. I. Jimenez San Cristobal - R. M. Hernandez (eds.), Redefining Dionysos, Berlin, Boston, 329-348.

W. F. Otto, Dionysus: Myth and Cult, Dallas.

V. Platt, "Viewing, Desiring, Believing: Confronting the Divine in a Pompeian House", Art History 25, 87112.

J. J. Pollitt, Art in the Hellenistic Age, Cambridge.

D. J. Rayor, Sappho: A New Translation of the Complete Works, Cambridge.

M. Robertson, A Shorter History of Greek Art, Cambridge.

C. Sourvinou-Inwood, “A Series of Erotic Pursuits: Images and Meanings”, JHS 107, 131-153.

A. Stewart, Greek Sculpture: an Exploration, New Haven.

A. Stewart, “Rape?”, E. D. Reeder (ed.), Pandora: Women in Classical Greece, Princeton, N.J., Baltimore, 7490.

A. Stewart, Art, Desire and the Body in Ancient Greece, Cambridge.

K. T. von Stackelberg, “Garden Hybrids: Hermaphrodite Images in the Roman House”, ClAnt 33 (2), 395-426.

R. F. Sutton, "Pornography and Persuasion on Attic Pottery", Amy Richlin (ed.), Pornography and Representation in Greece and Rome, New York, 3-35.

R. M. Taylor, The Moral Mirror of Roman Art, New York.

B. S. Thornton, Eros: The Myth of Ancient Greek Sexuality, Boulder, Colo.

A. Varone, Eroticism in Pompeii, Roma.

E. Vermeule, Aspects of Death in Early Greek Art and Poetry, Berkeley.

J. P. Vernant, Mortals and Immortals, Princeton, N.J. 